ISSN 0258-7122 (Print), 2408-8293 (Online)

Bangladesh J. Agril. Res. 41(4): 599-623, December 2016

\title{
PROFITABILITY OF SUNFLOWER CULTIVATION IN SOME SELECTED SITES OF BANGLADESH
}

\author{
M. Khatun ${ }^{1}$, TANVIR M. B. Hossain, M. A. MONAYEM MiaH ${ }^{2}$ \\ S. KHANDOKER ${ }^{1}$ AND M. A. RASHID ${ }^{3}$
}

\begin{abstract}
The study was conducted in Bogra and Satkhira districts to assess the socioeconomic status, profitability, problems and prospects of sunflower cultivation in Bangladesh. A total of 100 sunflower cultivating farmers, taking 50 farmers from each district, were randomly selected for this study. About $18 \%$ female farmers were also found to cultivate sunflower due to its beauty and easy cultivation method. Majority of the farmers had only one year experience of sunflower cultivation. Per hectare cost of producing sunflower was estimated as Tk. 62,199. Per hectare net return and BCR were Tk. 10,863 and 1.18, respectively which indicated that sunflower cultivation was profitable. Stochastic frontier function revealed that the use of labour, seed, organic fertilizers, cost of irrigation, and land type had positive and significant effect on the yield of sunflower. Average technical efficiency of the farmers was $86 \%$ which implies that there is a scope of increasing productivity of sunflower by $14 \%$ using current level of inputs by increasing the farmers' efficiency. Lack of irrigation facility, scarcity of seed on time, absence of sunflower oil mill and sunflower market, low demand for sunflower, high cost of seed, etc. were the major problems of sunflower production and marketing. In spite of having some problems $18 \%$ female farmers became interested to cultivate and $46 \%$ farmers of Satkhira district mentioned that their demand for edible oil is becoming fulfil. So there is great potentiality of sunflower cultivation in Bangladesh. The availability of sunflower seed with low cost and establishment of sunflower oil mill is needed to sustain this crop in Bangladesh. Therefore, import dependency on soybean oil will be reduced.
\end{abstract}

Keywords: Sunflower cultivation, financial profitability, technical efficiency and potentiality.

\section{Introduction}

Acute shortage of edible oil has been prevailing in Bangladesh during the last several decades. This shortage inherited from the past has been met through imports, using a huge amount of foreign exchange every year. Bangladesh produces 0.358 million tons of edible oil against the annual demand of 1.6 million tons, while the remaining 1.242 million tons of the country's domestic

${ }^{1}$ Scientific Officer, Agricultural Economics Division, Bangladesh Agricultural Research Institute (BARI), Gazipur, ${ }^{2}$ Senior Scientific Officer, Agricultural Economics Division, BARI, Gazipur, ${ }^{3}$ Principal Scientific Officer, Agricultural Economics Division, BARI, Gazipur, Bangladesh. 
requirements is met through imports (Hossain, 2014). The value of imported edible oils was Tk. 1, 38,141 million in 2014, (BB, 2014). Besides, the area under oilseeds cultivation is decreasing over the years due to various economic and technical reasons (Miah et al., 2014). The present total area under sunflower and other minor oilseed cultivation is 351.82 ha with a production of 373 metric tons in 2012 (BBS, 2012). The area under sunflower and other oilseeds cultivation is decreasing over the year (Figure 1). This decreasing trend might be due to other oilseeds and the area and production of sunflower is increasing with the initiatives of the DAE as well as some NGOs like BRAC and Islamic Relief, Bangladesh particularly in the coastal areas of Bangladesh. Area and production of these oilseeds was highest in the year of 2004-2005 this might be due to favourable environmental condition or for the initiatives of government and NGOs and after that year a downward trend of area and production is observed.

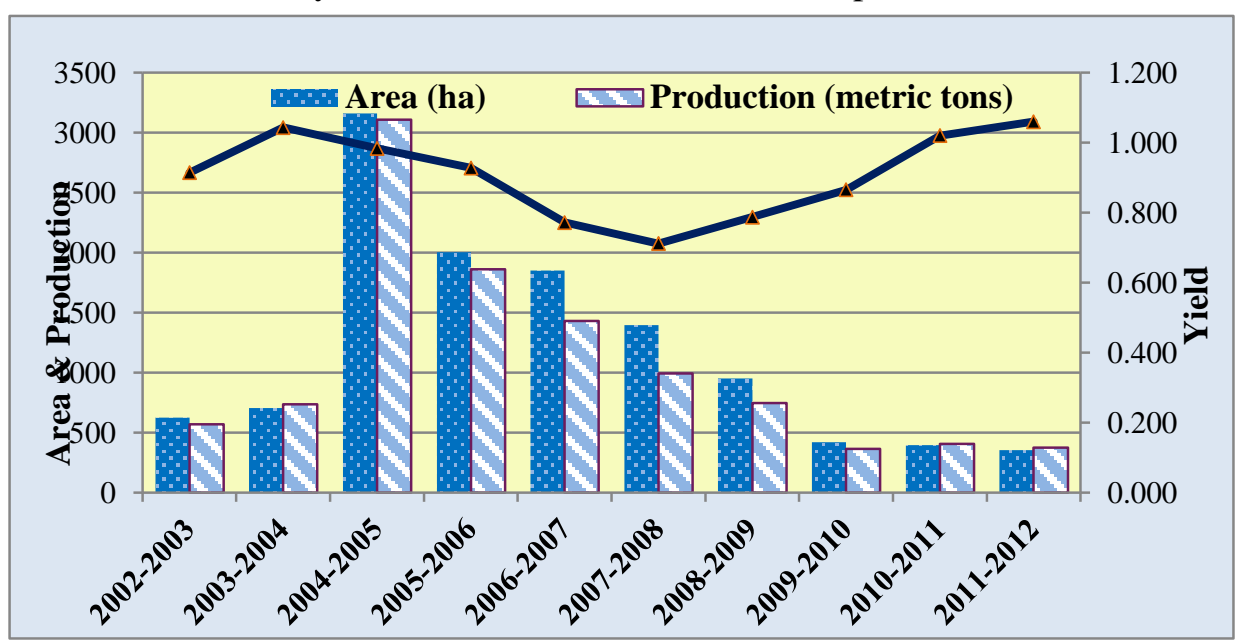

Source: Various issues of BBS

Fig. 1. Area, production and yield of other oil seed (sunflower, etc) in Bangladesh over the year 2002-2003 to 2011-2012

In such a situation, increasing production and marketing of oilseed will help us to reduce our import dependence on edible oils. In order to meet the increasing demand of edible oil sunflower can be emerged as an important oilseed crop in Bangladesh. According to Food and Agricultural Organization (FAO), sunflower ranges second subsequent to soybean as an oil crop in the world. Sunflower is a good substitute when it's difficult to cultivate other crops due to climate hazards.There is high demand for sunflower because its oil is good for health as it contains low cholesterol. One $\mathrm{kg}$ of sunflower seeds yields 500 to 600 grams of oil, which is more than that of any other oilseeds (Anon., 2015). Sunflower oil contributes about $13 \%$ of the world edible oil production with high value 
(Gabagambi et al., 2010). Due to its larger adaptation capability and higher oil quality, sunflower can be grown almost in all the regions of the world with high seed yield and oil content (Sencar et al., 1991). In Bangladesh, farmers have been cultivating sunflower since 1975 but in a small scale. However, farmers are becoming more interested to cultivate this oilseed crop for getting quality oil at lower costs. They are harvesting a good profit from sunflower farming after meeting their family requirements. They also cultivated it in one or two crop lands. Farmers are cultivating sunflower as an adaptation practices of climate change in the coastal region of Bangladesh. Sunflower of variety Hi-Sun-33 is adopted as rabi crop in coastal region of Jhalokathi for meeting up edible oil requirement as well as higher income and saving of foreign currency. BRAC has undertaken a pilot study to popularize sunflower in coastal belt and to develop local market for this crop and also has established a mill for oil extraction (Rahman, 2012). Two crop production cycles are also popular as nutrition requirement of crops is supplemented by each other cultivation like sunflower, chickpea and Khesari after the cultivation of T. Aman in coastal regions (Rashid et al., 2014). It is also accepted by coastal farmers to reduce food crisis. So it will be profitable to cultivate sunflower in Bangladesh particularly in the context of climate change, increasing soil salinity in the coastal areas, scarcity of irrigation facilities, etc.

For increasing the sunflower production across the country, it is needed to increase the area by utilizing the fallow land. To meet the demand of edible oil, increasing production, marketing facilities, and processing of sunflower seed is needed. Therefore, this study will figure out the profitability of sunflower, farmers' perception on the problems and prospects of sunflower cultivation. Recognizing the importance and suitability of sunflower cultivation following objectives were undertaken to examine.

\subsection{Objectives}

The specific objectives of this study were as follows:

i. To know the farmers' profile of sunflower cultivation;

ii. To know the sunflower cultivation practices of the farmers;

iii. To estimate the profitability level of sunflower cultivation;

iv. To estimate the technical efficiency of sunflower growers, and

v. To find out the problems and potentialities of sunflower cultivation.

\section{Methodology}

2.1 Sampling Procedure: Multistage sampling procedure was followed to collect sample farmers for this study. At first, two districts Bogra and Satkhira were purposively selected from Northern and Southern regions of Bangladesh 
respectively. In the second stage, two sunflower growing upazilas from each district were selected on the basis of area and production of sunflower. Thirdly, 2-3 agricultural Blocks were selected in consultation with DAE personnel for selecting sample farmers. Finally, a required number of samples were randomly selected from the complete list of sunflower farmers for interview.

2.2 Sample Size: The number of sample farmers to be selected is an important question among the researchers. When the population size is known or roughly so and the researchers are careful of the heterogeneity problem, any number (equal to or) greater than the statistically large sample (of 30 sample units) may be appropriate (Freund and Williams, 1983). However, a total of 100 sunflower growers taking 25 farmers from each Upazila were selected randomly from the list for the study.

2.3 Data Collection: The study was mainly based on primary data collected through face to face interview using a pre-tested interview schedule which was conducted through field survey during the month of December to April, 2015.

2.4 Analytical technique: The collected data were first edited and tabulated for analysis to fulfill the objectives of the study. Descriptive statistics such as averages and percentages were used in this study. Stochastic Cobb-Douglas production frontier model was used to estimate the technical efficiency of sunflower producer.

\subsubsection{Tabular Technique}

Profitability Analysis: Net Return has been calculated by deducting all costs (both variable and fixed) from gross return and gross margin has been calculated by deducting variable costs from Total Revenue.

\subsubsection{Statistical Technique}

Production Frontier Modeling: The stochastic Cobb-Douglas production frontier model was used for estimating technical efficiency of sunflower producer in the study areas and the model is given below:

$$
\ln Y_{i}=\beta_{0}+\beta_{1} \ln X_{1 i}+\beta_{2} \ln X_{2 i}+\ldots \ldots \ldots \ldots . . .+\beta_{n} \ln X_{n i}+V_{i}-U_{i}
$$

Where, ln represents the natural logarithm; the subscript i represents the $i$-th farmer in the sample, $Y$ represents the quantity of sunflower harvest in kilogram, $\mathrm{X}_{\mathrm{i}}$ represents the variable factors of production, $\beta \mathrm{i}$ unknown parameters to be estimated, $\mathrm{V}_{\mathrm{i}}$ assumed to be independently and identically distributed (iid) random errors, having $\mathrm{N}\left(0, \sigma_{\mathrm{v}}^{2}\right)$ distribution, $\mathrm{u}_{\mathrm{i}}$ are non-negative one sided random variables, called technical inefficiency effects, associated with the technical inefficiency of production of the farmers involved. It is assumed that 
the inefficiency effects are independently distributed with a half normal distribution $\left(\mathrm{U} \sim\left|\mathrm{N}\left(0, \sigma_{\mathrm{v}}{ }^{2}\right)\right|\right)$.

To examine the role of relevant farm specific variables in efficiency, the production inefficiency effect model can be written as follows:

$$
\mathrm{Ui}=\delta_{0}+\delta_{1} \mathrm{Z}_{1 \mathrm{i}}+\delta_{2} \mathrm{Z}_{2 \mathrm{i}}+\ldots . .+\delta_{\mathrm{n}} \mathrm{Z}_{\mathrm{ni}}+\mathrm{W}_{\mathrm{i}}
$$

Where, $Z_{i}$ represents the farm specific inefficiency variable factors of production, $\delta_{\mathrm{i}}$ unknown parameters to be estimated, $\mathrm{W}_{\mathrm{i}}$ unobservable random variables, which are assumed to be independently distributed with a positive half normal distribution.

The empirical Cobb-Douglas stochastic frontier production function with double $\log$ form can be expressed as:

$$
\begin{aligned}
\ln Y_{i}= & \beta_{0}+\beta_{1} \ln X_{1 i}+\beta_{2} \ln X_{2 i}+\beta_{3} \ln X_{3 i}+\beta_{4} \ln X_{4 i}+\beta_{5} \ln X_{5 i}+\beta_{6} \ln X_{6 i} \\
& +\eta_{1} D_{1 i}+v_{i}-u_{i}
\end{aligned}
$$

Where, $\mathrm{Ln}=$ Natural logarithm,

$Y_{i}=$ Yield of sunflower of the i-th farm $(\mathrm{kg} / \mathrm{ha})$

$\mathrm{X}_{1}=$ Human labour used by the $\mathrm{i}$-th farm (man-days /ha)

$\mathrm{X}_{2}=$ Seed used by the $\mathrm{i}$-th farm $(\mathrm{kg} / \mathrm{ha})$

$\mathrm{X}_{3}=$ Land preparation cost used for the $\mathrm{i}$-th farm (Tk. /ha)

$\mathrm{X}_{4}=$ Irrigation cost used for the i-th farm (Tk. /ha)

$\mathrm{X}_{5}=$ Organic Nutrient (Manure) used by the $\mathrm{i}$-th farm $(\mathrm{kg} / \mathrm{ha})$

$\mathrm{X}_{6}=$ Inorganic Nutrient (Chemical fertilizers) used by the i-th farm $(\mathrm{kg} / \mathrm{ha})$

$D_{1 i}=$ Dummy for land type of the i-th farm $(1=$ Medium high land, $0=$ otherwise)

$\beta$ 's and $\eta$ 's are unknown parameters to be estimated

$\mathrm{v}_{\mathrm{i}}-\mathrm{u}_{\mathrm{i}}=$ error term

$\mathrm{V}_{\mathrm{i}}$ are assumed to be independently and identically distributed random errors, having $\mathrm{N}\left(0, \sigma_{v}^{2}\right)$ distribution.

Technical Inefficiency Effect Modeling: The $\mathrm{u}_{\mathrm{i}}$ 's in equation (1) are nonnegative random variables, called technical inefficiency effects, assumed that to be independently distributed such that the technical inefficiency effects for the ith farmer, $\mathrm{u}_{\mathrm{i}}$, are obtained by truncation normal distribution with mean zero and variance $\sigma_{u}^{2}$, such that 
$u_{i}=\delta_{0}+\delta_{1} Z_{1 i}+\delta_{2} Z_{2 i}+\delta_{3} Z_{3 i}+\delta_{4} Z_{4 i}+W_{i}$

Where, $Z_{1}=$ Age of the $i$-th farm operator (years)

$\mathrm{Z}_{2}=$ Education of the $\mathrm{i}$-th farm operator (year of schooling)

$\mathrm{Z}_{3}=$ Household size of the i-th farm operator (persons/household)

$\mathrm{Z}_{4}=$ Farm size of the $\mathrm{i}$-th farm operator (ha)

$\delta$ 's are unknown parameters to be estimated

$\mathrm{W}_{\mathrm{i}}$ are unobservable random variable or classical disturbance term, which are assumed to be independently distributed, obtained by truncation of the normal distribution with mean zero and unknown variance $\sigma^{2}$, such that $u_{i}$ is nonnegative.

The $\beta, \eta$ and $\delta$ coefficients are unknown parameters to be estimated, together with the variance parameters which are expressed in term of

$$
\begin{array}{ll} 
& \sigma^{2}=\sigma_{u}^{2}+\sigma_{v}^{2} \\
\text { and } \quad & \gamma=\sigma_{u}^{2} / \sigma^{2}
\end{array}
$$

$\gamma$ is the ratio of variance of farm specific technical efficiency to the total variance of output and has a value between zero and one.

The estimates for all parameters of the stochastic frontier and inefficiency model were estimated in a single stage by using the Maximum Likelihood (ML) method. The econometric computer software package FRONTIER 4.1 (Coelli, 1996) was applied to estimate the parameters of stochastic frontier models using the ML.

\section{Results and Discussion}

\subsection{Farmers' Profile}

Age of the farmers: The age distribution of the farmers is presented in Table 1. The age of the farmers were grouped into four age ranged. The $1^{\text {st }}$ group was ranged as 20-34 yrs, $2^{\text {nd }}$ group was $35-49$ yrs, $3^{\text {rd }}$ group was 50-64 yrs, and $4^{\text {th }}$ group was 65-80 yrs. Among the farmers $44 \%$ were belonged to 35-49 yrs age group, $25 \%$ farmers were at the age group of $20-34 \mathrm{yrs}$, and another $25 \%$ farmers were at the age group of 50-64 yrs.

Sex distribution of the farmers: Majority of the sunflower cultivators were male farmers $(82 \%)$. A good number of female farmers were also found to cultivate sunflower due to its beauty and easy cultivation method. In Bogra, 26\% farmers were female and they got support from BRAC to cultivate sunflower. There were also few female farmers (10\%) observed in Satkhira district (Table 2). 
Table 1. Percent distribution of average age of the respondent farmers

\begin{tabular}{ccccc}
\hline Age group (Year) & Bogra & Satkhira & All area \\
\hline $20-34$ & 14 & 36 & 25 \\
$35-49$ & 46 & 42 & 44 \\
$50-64$ & 28 & 22 & 25 \\
$65-80$ & 12 & - & 6 \\
Total & 100 & 100 & 100 \\
\hline
\end{tabular}

Table 2. Percent distribution of male and female farmers in the study areas

\begin{tabular}{lcccc}
\hline Sex of the farmer & Bogra & Satkhira & All areas \\
\hline Female & 26 & 10 & 18 \\
Male & 74 & 90 & 82 \\
Total & $\mathbf{1 0 0}$ & $\mathbf{1 0 0}$ & $\mathbf{1 0 0}$ \\
\hline
\end{tabular}

Education level of the farmers: The level of education of the respondent farmers was categorized into six groups. It was revealed that the highest percentage of farmers $(30 \%)$ had primary level of education. Farmers of Satkhira district were more educated than that of Bogra. Most of the farmers $(38 \%)$ of Satkhira district had primary level of education. In Bogra district, the highest percentage of sunflower farmers (48\%) was illiterate or can sign only (Table 3 ).

Table 3. Percent distribution of farmers according to their educational qualification

\begin{tabular}{lcccc}
\hline Level of education & Bogra & Satkhira & All area \\
\hline Illiterate & 24 & 4 & 14 \\
Can sign & 24 & 8 & 16 \\
Primary & 22 & 38 & 30 \\
Junior & 16 & 26 & 21 \\
SSC & 14 & 20 & 17 \\
Bachelor and above & - & 4 & 2 \\
Total & $\mathbf{1 0 0}$ & $\mathbf{1 0 0}$ & $\mathbf{1 0 0}$ \\
\hline
\end{tabular}

Professional status of the farmers: The professional status of the farmers was presented in the Table 4. It was reported that most of the respondent farmers $(93 \%)$ took agriculture as their main profession and the highest percentage of farmers had no subsidiary occupation (70\%). Similarly, most of the respondent farmers of Bogra district (96\%) were largely dependent on agriculture and $72 \%$ of them had no secondary occupation. 
Table 4. Percent distriburition of farmers according to their occupational status

\begin{tabular}{lcc|c}
\hline Occupation & Bogra & Satkhira & All area \\
\hline Main Occupation & & & \\
Agriculture & 96 & 90 & 93 \\
Business & 2 & 6 & 4 \\
Others & 2 & 4 & 3 \\
Subsidiary Occupation & & & \\
Agriculture & 4 & 8 & 6 \\
Business & 8 & 14 & 11 \\
No Profession & 72 & 68 & 70 \\
Others & 16 & 10 & 13 \\
\hline
\end{tabular}

Family size of farm household: The family size of the farmers was categorized according to the number of family members in the family. The family size is categorized by 3 categories i.e. number of members 1 to 4 persons, 5 to 8 persons, and 9 to 12 persons. The highest percentage of the farmers of Bogra district (60\%) had 5-8 family members. In Satkhira, the number of family members was 1 to 8 persons, but majority (56\%) of them had 1 to 4 family members (Table 5).

Table 5. Percent distribution of farmers according to family members

\begin{tabular}{l|c|c|c}
\hline Family member & Bogra & Satkhira & All area \\
\hline $1-4$ & 36 & 56 & 46 \\
$5-8$ & 60 & 44 & 52 \\
$9-12$ & 4 & - & 2 \\
Total & $\mathbf{1 0 0}$ & $\mathbf{1 0 0}$ & $\mathbf{1 0 0}$ \\
\hline
\end{tabular}

Household earning persons of the farm household: In the farm household family, the highest percentage of all farmers (64\%) had only one (1) earning person. One earning person per family was higher in Satkhira (72\%) than that of Bogra (56\%). But the number of two and three earning persons was higher among the farm families of Bogra district (Table 6).

Table 6. Percent distribution of household earning person

\begin{tabular}{c|c|c|c}
\hline Number of earning person & Bogra & Satkhira & All areas \\
\hline 1 person & 56 & 72 & 64 \\
2 persons & 30 & 22 & 26 \\
3 persons & 14 & 6 & 10 \\
Total & $\mathbf{1 0 0}$ & $\mathbf{1 0 0}$ & $\mathbf{1 0 0}$ \\
\hline
\end{tabular}


Annual income: Annual household income of the farmers was categorized into five groups. Majority of the farmers' annual incomes were within the range of Tk. 25,000 to Tk.1, 00,000. A good percentage of the farmers (26\%) of Bogra district had annual income ranged from Tk. 1,00,001 to Tk.1,75,001. Only $2 \%$ farmers of Bogra had annual income between Tk. 4,00,005 and Tk. 4,75,005 (Table 7).

Table 7. Percent distribution of respondent farmers according to household income

\begin{tabular}{l|c|c|c}
\hline Annual Income (Tk.) & Bogra & Satkhira & All area \\
\hline $25000-100000$ & 62 & 70 & 66 \\
$100001-175001$ & 26 & 12 & 19 \\
$175002-250002$ & 10 & 12 & 11 \\
$250003-325003$ & - & 4 & 2 \\
$400005-475005$ & 2 & - & 1 \\
Total & $\mathbf{1 0 0}$ & $\mathbf{1 0 0}$ & $\mathbf{1 0 0}$ \\
\hline
\end{tabular}

Farm size of the farmers: Farm size was categorized by marginal, small, medium and large farms. Majority of the farmers were smallholder. Among all sample farmers, $70 \%$ were small farmers, $17 \%$ were medium farmers, and $11 \%$ were marginal farmers. Only a small percentage of farmers $(4 \%)$ belonged to the large farm category (Table 8 ).

Table 8. Percent distribution of farmers according to their farm size category

\begin{tabular}{c|c|c|c}
\hline Farm category & Bogra & Satkhira & All areas \\
\hline Marginal & 12 & 10 & 11 \\
Small & 74 & 66 & 70 \\
Medium & 14 & 20 & 17 \\
Large & - & 4 & 2 \\
Total & $\mathbf{1 0 0}$ & $\mathbf{1 0 0}$ & $\mathbf{1 0 0}$ \\
\hline
\end{tabular}

Note: Large farm $=$ above 3.03 ha, Medium farm $=1-3.03$ ha, Small farm $=0.19$ 0.99 ha, Marginal farm $=0.01-0.18 \mathrm{ha}$

Land use pattern of farmers: Respondent farmers generally utilize their own cultivable lands and other lands for cultivating different crops. The average farm size of the farmers was higher in Satkhira district ( 0.79 ha) compared to the farm size of Bogra district ( 0.67 ha). But the opposite scenario was observed in the farmers' own cultivable land size. Respondent farmers cultivated sunflower on an average 0.13 ha of land which was $32 \%$ of their net cultivated land. Land under sunflower cultivation was higher in Bogra (38\% of their net cultivated land) compared to Satkhira (Table 9). 
Table 9. Land use pattern of the farmers (ha)

\begin{tabular}{l|c|c|c}
\hline Land use pattern & Bogra & Satkhira & Total \\
\hline Farm size & 0.67 & 0.79 & 0.73 \\
Own cultivable land & 0.76 & 0.70 & 0.72 \\
Net cultivated land & 0.61 & 0.62 & 0.61 \\
Land under sunflower cultivation & 0.17 & 0.09 & 0.13 \\
Share of sunflower in net cultivated land (\%) & 38 & 27 & 32 \\
\hline
\end{tabular}

Farmers' experiences: Farmers' experience in oilseed cultivation was higher in Bogra district but the experience of sunflower cultivation was higher in Satkhira district. The highest percentage of farmers $(67 \%)$ had oilseed cultivation experiences within 0 to 10 years (Table-10). About $96 \%$ farmers had experiences within the range of 0 to 10 years which was higher in Satkhira district. A good percentage of farmers $(21 \%)$ had also experience within the years ranged from 11 to 21 years. A higher percentage of the farmers in Bogra district (38\%) had oilseed cultivation experiences within the years ranged from 11 to 21 years.

Majority of the farmers of Bogra district (82\%) had only one year experience in sunflower cultivation. But in Satkhira district majority of the farmers (48\%) had two years of experience in sunflower cultivation. A good number of farmers of Satkhira district (24\%) had three years of experience in sunflower cultivation. A small number of farmers also had four to five years of experiences (Table 11).

Table 10. Percent distribution of farmers according to their farming experience in oilseed cultivation

\begin{tabular}{c|c|c|c}
\hline Range of experience (year) & Bogra & Satkhira & All area \\
\hline $0-10$ & 38 & 96 & 67 \\
$11-21$ & 38 & 4 & 21 \\
$22-32$ & 14 & - & 7 \\
$33-43$ & 8 & - & 4 \\
$44-54$ & 2 & - & 1 \\
Total & $\mathbf{1 0 0}$ & $\mathbf{1 0 0}$ & $\mathbf{1 0 0}$ \\
\hline
\end{tabular}

Table 11. Percent distribution of farmers according to their experience in sunflower cultivation

\begin{tabular}{c|c|c|c}
\hline Years & Bogra & Satkhira & All areas \\
\hline 1 & 82 & 24 & 53 \\
2 & 18 & 48 & 33 \\
3 & - & 24 & 12 \\
4 & - & 2 & 1 \\
5 & - & 2 & 1 \\
Total & $\mathbf{1 0 0}$ & $\mathbf{1 0 0}$ & $\mathbf{1 0 0}$ \\
\hline
\end{tabular}




\subsection{Farmers' Motivation to Sunflower Cultivation}

All the respondent farmers of Bogra district cultivated sunflower at the first time due to the inspiration of BRAC (a non-government organization). But in Satkhira district, respondent farmers inspired by BRAC, neighbouring farmers and BARI scientists. A good number of farmers of Satkhira district (30\%) cultivated sunflower motivated by BARI scientists Neighbouring sunflower farmer also motivated sample farmers to cultivate sunflower (Table 12).

Table 12. Percent distribution of farmers according to the source of motivation for cultivating sunflower at the first

\begin{tabular}{l|c|c|c}
\hline Source of motivation & Bogra & Satkhira & All area \\
\hline BRAC personnel & 100 & 62 & 81 \\
Neighbouring farmers & - & 8 & 4 \\
BARI scientists & - & 30 & 15 \\
\hline
\end{tabular}

Kind of support: BRAC provided both technical and monetary supports (Tk. 5500/acre) to the farmers for cultivating sunflower. Respondent farmers also received technological supports (improved seed \& management technologies) from BARI scientists to cultivate sunflower. Table 13 shows that one hundred percent farmers of Bogra district received money and $24 \%$ farmers received training from BRAC. But in Satkhira, the farmers (38\%) who cultivated sunflower with the support of others except BRAC mentioned that they received improved sunflower seed as a support.

Table 13. Percent distribution of farmers according to the supports received at first time of sunflower cultivation

\begin{tabular}{l|c|c|c}
\hline Kind of support & Bogra & Satkhira & All area \\
\hline Seed & - & 38 & 19 \\
Money & 100 & 62 & 81 \\
Training & 24 & 14 & 19 \\
\hline
\end{tabular}

\section{Factors Responsible for Choosing Sunflower Cultivation}

Respondent farmers were influenced by different factors to cultivate sunflower. Table 14 reveals that about half of the farmers of Bogra district cultivated sunflower because of getting technical and monetary support from BRAC. In Satkhira district, $84 \%$ farmers cultivated sunflower because it was more profitable than other crops. Due to lower cost of production about $82 \%$ farmers of Satkhira district preferred this crop to cultivate. A good number of the farmers $(25 \%)$ mentioned that sunflower cultivation is more profitable than other oilseed crops and that's why they cultivated. Another $6 \%$ farmers cultivated sunflower for getting edible oil for household consumption. Farmers in Satkhira district 
pointed out another two factors for choosing sunflower cultivation which were assured market for the produce (4\%) and land suitability for sunflower cultivation (2\%). Again, some farmers of Bogra district (2\%) cultivated sunflower due to higher yield (Table 14).

Table 14. Percent responses on the factors that influence farmers to cultivate sunflower

\begin{tabular}{l|c|c|c}
\hline \multicolumn{1}{c|}{ Factors } & Bogra & Satkhira & All area \\
\hline More profitable than other crops & 34 & 84 & 59 \\
Lower cost of production & 24 & 82 & 53 \\
Getting support from BRAC & 50 & 14 & 32 \\
More profitable than other oilseed crops & 18 & 32 & 25 \\
For edible oil & 2 & 10 & 6 \\
Assured market for the produce & - & 4 & 2 \\
Land is suitable only for sunflower cultivation & - & 2 & 1 \\
High yield & 2 & - & 1 \\
\hline
\end{tabular}

\subsection{Present Situation of Sunflower Cultivation}

Farmers of Satkhira district were more interested in cultivating sunflower and $18 \%$ of them cultivated it without any support from others. Another $18 \%$ farmers cultivated it with the support of BARI. About $64 \%$ farmers cultivated with the support of BRAC. But in Bogra, all most all of the farmers $(96 \%)$ cultivated sunflower with the support of BRAC and only $4 \%$ farmers cultivated it without any support from outside (Table 15).

Table 15. Cultivating sunflower with the support of BRAC or BARI

\begin{tabular}{l|c|c|c}
\hline Particulars & Bogra (\%) & Satkhira (\%) & All areas (\%) \\
\hline With the support of BRAC & 96 & 64 & 80 \\
With the support of BARI & - & 18 & 9 \\
With own will & 4 & 18 & 11 \\
Total & $\mathbf{1 0 0}$ & $\mathbf{1 0 0}$ & $\mathbf{1 0 0}$ \\
\hline
\end{tabular}

\subsection{Adoption of Sunflower Variety}

Two varieties of sunflower, namely High Sun-33 and Kironi (DS-1) were found to cultivate in the study areas. The adoption of BARI variety (Kironi DS-1) was found only at Satkhira district. All the farmers of Bogra and $70 \%$ farmers of Satkhira district cultivated High Sun-33 variety and only 30\% farmers of Satkhira district cultivated Kironi variety of sunflower (Table 16).The main reason of this low adoption was unavailability of seed in the study areas. 
Table 16. Varietal adoption of sunflower in the study areas

\begin{tabular}{lcccc}
\hline Name of the variety & Bogra $(\%)$ & Satkhira $(\%)$ & All areas $(\%)$ \\
\hline High Sun-33 & 100 & 70 & 85 \\
Kironi (DS-1) & - & 30 & 15 \\
Total & $\mathbf{1 0 0}$ & $\mathbf{1 0 0}$ & $\mathbf{1 0 0}$ \\
\hline
\end{tabular}

\subsection{Sources of Seed}

Farmers in the study areas mentioned that they received seed of sunflower from four sources. Average $75 \%$ farmers in the study areas bought seed from BRAC and $10 \%$ from local market. Only $18 \%$ and $12 \%$ farmers of Satkhira district received seed from BARI and neighbouring farmers respectively (Table 17).

Table 17. Sources of seeds of sunflower in the study areas

\begin{tabular}{l|c|c|c}
\hline Sources of seed & Bogra $(\%)$ & Satkhira $(\%)$ & All areas $(\%)$ \\
\hline BRAC & 86 & 64 & 75 \\
BARI & - & 18 & 9 \\
Local market & 14 & 6 & 10 \\
Neighbouring farmers & - & 12 & 6 \\
Total & $\mathbf{1 0 0}$ & $\mathbf{1 0 0}$ & $\mathbf{1 0 0}$ \\
\hline
\end{tabular}

\subsection{Cropping Pattern}

A total of 4 sunflower based cropping patterns were found in the study areas. The highest percentage of the farmers $(35 \%)$ in all areas followed Sunflower-AusAman cropping pattern and 32\% farmers followed Sunflower-Fallow-Aman cropping pattern. The highest percentage of farmers in Bogra district (60\%) followed Sunflower-Aus-Aman cropping pattern and the highest $42 \%$ farmers of Satkhira district followed Sunflower-Fallow-Aman cropping pattern. Farmers cultivated sunflower following Sunflower-Aus-Aman (35\%), Sunflower-FallowAman (32\%), Sunflower-Jute-Aman (18\%) and Sunflower-Fallow-Fallow (15\%) cropping pattern (Table 18).

Table 18. Percent distribution of different cropping patterns followed by the farmers in sunflower cultivation

\begin{tabular}{c|lc|c|c}
\hline Sl. No. & \multicolumn{1}{|c|}{ Cropping pattern } & Bogra & Satkhira & All areas \\
\hline 1 & Sunflower -Aus-Aman & 60 & 10 & 35 \\
2 & Sunflower-Fallow-Aman & 22 & 42 & 32 \\
3 & Sunflower-Jute-Aman & 18 & 18 & 18 \\
4 & Sunflower -Fallow-Fallow & - & 30 & 15 \\
& Total & $\mathbf{1 0 0}$ & $\mathbf{1 0 0}$ & $\mathbf{1 0 0}$ \\
\hline
\end{tabular}




\subsection{Agronomic Practices}

All the agronomic practices are shown in Table 19. The farmers ploughed 3.5 times followed by two times laddering for land preparation in sunflower cultivation. Sunflower is grown all the year round in Bangladesh, but it gives better yield in Rabi season (Anon., 2014). In the study areas, farmers cultivated sunflower during Rabi season (mid-November to mid-December). Most of the farmers sowed seed in line and only $6 \%$ farmers of Satkhira district followed broadcasting method of sowing. They performed some intercultural operations like weeding, spraying, and irrigating the crop. The average number of weeding, irrigation, and insecticide spraying per farm were 3,2 , and 1.5 respectively. The harvesting time of sunflower started in the month of March and continued up to the month of April.

Table 19. Agronomic practices of sunflower cultivation in the study areas

\begin{tabular}{|c|c|c|c|}
\hline Agronomic practices & Bogra & Satkhira & All area \\
\hline No. of ploughing & 4 & 3 & 3.5 \\
\hline No. of laddering & 2 & 2 & 2 \\
\hline Time of sowing & $\begin{array}{l}\text { Mid November-mid } \\
\text { December }\end{array}$ & $\begin{array}{l}\text { Mid November-mid } \\
\text { December }\end{array}$ & $\begin{array}{l}\text { Mid November- } \\
\text { mid December }\end{array}$ \\
\hline \multicolumn{4}{|l|}{ Planting method $(\%)$} \\
\hline Line & 100 & 94 & 97 \\
\hline Broadcasting & 0 & 6 & 3 \\
\hline No. of weeding & 3 & 3 & 3 \\
\hline No. of irrigation & 2 & 2 & 2 \\
\hline No. of spraying & 2 & 1 & 1.5 \\
\hline Time of harvesting & March-April & March-April & March-April \\
\hline
\end{tabular}

\subsection{Cost and Returns of Sunflower Cultivation}

Inputs use pattern in sunflower cultivation: On an average 146.13 man-days of human labour is required to cultivate one hectare of land. Farmers in the study areas used more family labour (76.56 man-days/ha) and a lot of women labour also worked in sunflower field. On an average, $7 \mathrm{~kg}$ seed was sown in one hectare of land. Farmers used both bio and chemical fertilizer. Farmers of Bogra district applied slightly higher dose of Urea, TSP and MoP than that of Satkhira district. Again, the farmers of Satkhira district applied slightly higher dose of gypsum, Zinc and Boron than that of Bogra district (Table 20). 
Table 20. Per hectare input use pattern of sunflower cultivation

\begin{tabular}{lcccc}
\hline \multicolumn{1}{c|}{ Inputs } & Bogra & Satkhira & All area \\
\hline Human labour (man-day) & 145.36 & 146.90 & 146.13 \\
$\quad$ Family labour & 73.23 & 79.88 & 76.56 \\
$\quad$ Hired labour & 72.13 & 67.02 & 69.57 \\
Seed (kg) & 6.86 & 7.29 & 7.08 \\
Bio-fertilizer (ton) & 6.40 & 6.70 & 6.51 \\
Urea (kg) & 155.68 & 147.48 & 151.58 \\
TSP (kg) & 61.60 & 57.20 & 59.40 \\
MoP (kg) & 70.64 & 67.70 & 69.23 \\
Gypsum (kg) & 57.61 & 58.74 & 58.06 \\
Zinc (kg) & 6.50 & 7.48 & 6.53 \\
Boron (kg) & 5.33 & 7.48 & 5.62 \\
\hline
\end{tabular}

Table 21. Per hectare cost of sunflower cultivation in the study areas

\begin{tabular}{|c|c|c|c|c|c|c|}
\hline \multirow{2}{*}{ Cost Items } & \multicolumn{2}{|c|}{ Bogra } & \multicolumn{2}{|c|}{ Satkhira } & \multicolumn{2}{|c|}{ All areas } \\
\hline & (Tk./ha) & $(\%)$ & (Tk./ha) & $(\%)$ & (Tk./ha) & $(\%)$ \\
\hline \multicolumn{7}{|l|}{ A. Cash costs } \\
\hline Cost of land preparation & 5403 & 9 & 4457 & 7 & 4930 & 8 \\
\hline Hired labour & 14672 & 24 & 13107 & 20 & 13775 & 22 \\
\hline Cost of seed & 8718 & 14 & 10617 & 17 & 9668 & 16 \\
\hline Bio-fertilizer & 2284 & 4 & 2568 & 4 & 2426 & 4 \\
\hline Chemical fertilizers & 6954 & 11 & 5240 & 8 & 6097 & 10 \\
\hline Urea & 2865 & 5 & 2450 & 4 & 2657 & 4 \\
\hline TSP & 1508 & 2 & 1424 & 2 & 1466 & 2 \\
\hline MoP & 1204 & 2 & 1105 & 2 & 1157 & 2 \\
\hline Zinc & 1037 & 2 & 1123 & 2 & 1040 & 2 \\
\hline Gypsum & 520 & 1 & 542 & 1 & 529 & 1 \\
\hline Boron & 828 & 1 & 1325 & 2 & 895 & 1 \\
\hline Cost of irrigation & 3392 & 6 & 5904 & 9 & 4648 & 7 \\
\hline Cost of pesticides & 1282 & 2 & 1333 & 2 & 1308 & 2 \\
\hline Total cash cost & 28090 & 46 & 30492 & 48 & 29291 & 47 \\
\hline IOC@6\% for 4 months & 281 & 0.46 & 310 & 0.48 & 295 & 0.47 \\
\hline Family labour & 14922 & 25 & 15409 & 24 & 15165 & 24 \\
\hline Land use cost & 17430 & 29 & 17465 & 27 & 17447 & 28 \\
\hline Total cost & 60723 & 100 & 63676 & 100 & 62199 & 100 \\
\hline
\end{tabular}


Cost of sunflower cultivation: Costs are the expenses incurred for carrying out the process of production. The cost of producing sunflower included different variable cost items like human labour, seed, fertilizer, irrigation, insecticides etc. Both cash expenditure and imputed value of family supplied inputs (i.e. labour, land) were included in the analysis. Besides, interest on operating capital was also considered for the estimation of cost of sunflower production. The cost of land use was calculated on the basis of lease value of land. Per hectare total cost of sunflower cultivation was estimated at Tk. 62,199 in which the share of cash cost was $47 \%$ (Table 21). Human labour was the major cost items incurred in both areas, which covered about $40 \%$ of total cost. A large number of family labour ( $24 \%$ of total cost) was engaged in sunflower cultivation. Among the cash cost items, the second highest share of total cost was for seeds (16\%). The cost of chemical fertilizer in Bogra district (Tk. 6954/ha) was slightly higher than that of Satkhira district (Tk. 5240/ha) due to using comparatively high amount of fertilizer. The cost of irrigation was comparatively high in Satkhira district (Tk. 5904/ha) because there existed saline water. The cost of fresh water is high and farmers used less irrigation in sunflower cultivation.

Profitability of sunflower cultivation: The average yield of sunflower was 2.09 ton/ha which is higher than that of other oilseed crops. Miah et al. (2013) found the average yields of improved sesame and mustard varieties to be 1.46 ton/ha and 1.64 ton/ha respectively. Although the yield difference found between two districts was not prominent, the variation of gross return was high due to higher price of sunflower in Satkhira district. Average gross margin was found to be Tk. 43,576 /ha. Per hectare net return from sunflower cultivation was found Tk. 10,863 which indicates sunflower cultivation is profitable (Table 22). Return above full cost and cash cost were estimated at 1.18 and 2.50 respectively which indicate if the cost of production is $1 \mathrm{Tk}$. then returns will be Tk. 1.18 and Tk. 2.50 for full cost and cash cost basis respectively. The average cost of producing per $\mathrm{kg}$ of sunflower was Tk. 30 which indicates that farmers get $32 \mathrm{Tk}$. per $\mathrm{kg}$ from selling sunflower seed by spending $30 \mathrm{Tk}$. per $\mathrm{kg}$ for production. Therefore, the profit margin from sunflower production seems to be marginal. However, if the profit margin in terms of return above cash cost is considered this would be high enough for the farmers to continue sunflower production particularly for the farming households having excess family labour including women. Rahman (2012) estimated per hectare average yield, gross return and BCR of sunflower at coastal region were 3.12 ton, Tk. 114,841 and 2.87 respectively. Rashid et al. (2014) showed the seed yield, cost and return of sunflower was affected by the date of sowing. They found the highest seed yield and BCR were produced from 14 January planting (3.06 tha-1 and 2.32, respectively). 
Table 22. Per hectare profitability of sunflower cultivation

\begin{tabular}{lcccc}
\hline \multicolumn{1}{c|}{ Particulars } & Bogra & Satkhira & All area \\
\hline A. Yield (Ton/ha) & 2.02 & 2.15 & 2.09 \\
B. Price (Tk./kg) & 31 & 33 & 32 \\
C. Gross return (Tk.) & 68938 & 77387 & 73163 \\
\multicolumn{1}{c}{ Main product (Tk.) } & 62620 & 70950 & 66785 \\
\multicolumn{1}{c}{ By-product (Tk.) } & 6318 & 6437 & 6378 \\
D. Total cash cost (Tk.) & $\mathbf{2 8 0 9 0}$ & $\mathbf{3 0 4 9 2}$ & $\mathbf{2 9 2 9 1}$ \\
E. Total variable cost (Tk.) & 28371 & 30802 & 29587 \\
F. Gross Margin (C-E) & 40567 & 46585 & 43576 \\
G. Total fixed cost (Tk.) & 32352 & 32874 & 32613 \\
H. Total cost (E+G) & 60723 & 63676 & 62199 \\
I. Net Return (C-H) & 8015 & 13711 & 10863 \\
J. Return above cash cost (C/D) & 2.45 & 2.54 & 2.50 \\
K. Return above full cost (C/H) & 1.14 & 1.22 & 1.18 \\
L. Cost of production (Tk/kg) & 30 & 30 & 30 \\
\hline
\end{tabular}

\subsection{Marketing of Sunflower}

There was no specific market for selling sunflower in the study areas. On an average, $35 \%$ farmers sold their produce to local market and 52\% of them sold to local traders (Table 23). Most of the farmers of Bogra district (74\%) sold the major portion of their produce to traders who were informed by BRAC. In Satkhira, farmers sold sunflower by converting it into oil. About $20 \%$ farmers didn't sell their produce, they only cultivated sunflower for oil purpose. The other farmers of Satkhira sold it to the traders (30\%), local markets $(26 \%)$, and shops $(6 \%)$.

Table 23. Selling status of sunflower in the study areas

\begin{tabular}{lcccc}
\hline Particulars & Bogra (\%) & Satkhira (\%) & All areas (\%) \\
\hline Local market & 44 & 26 & 35 \\
Specific institute & 8 & - & 4 \\
Traders & 74 & 30 & 52 \\
Didn't sell & - & 20 & 10 \\
Shop & - & 6 & 3 \\
\hline
\end{tabular}




\subsection{Demands for Sunflower}

Majority of the farmers of Satkhira district (86\%) identified the demand for sunflower oil as moderate high (Table 24). On the other hand, opposite scenario was observed in Bogra. Most of the farmers of Bogra district (58\%) mentioned that the demand of sunflower in the market is low, $20 \%$ marked it as very low and only $22 \%$ reported it as moderately high.

Table 24. Farmers' perceptions about demand for sunflower in the market

\begin{tabular}{l|c|c|c}
\hline Category of demand & Bogra $(\%)$ & Satkhira $(\%)$ & All areas (\%) \\
\hline Very High & - & 6 & 3 \\
Moderate high & 22 & 86 & 54 \\
High & - & 8 & 4 \\
Low & 58 & - & 29 \\
Very low & 20 & - & 10 \\
Total & $\mathbf{1 0 0}$ & $\mathbf{1 0 0}$ & $\mathbf{1 0 0}$ \\
\hline
\end{tabular}

\subsection{Utilization of Sunflower Seed}

Utilization of sunflower at farmers' level: Farmers consumed sunflower seed as edible oil (82\%) and its by-product used as fuel (45\%). Very small percentage of farmers mentioned that sunflower seed can be eaten as fry like groundnut $(6 \%)$ and as dish of boiled sunflower (4\%) (Table 25). But in developed countries like Sweden biodiesel is also produced from sunflower seed (Sales, 2011).

Table 25. Utilization of sunflower seed at farmers' level in the study areas

\begin{tabular}{l|c|c|c}
\hline Utilizations & Bogra $(\%)$ & Satkhira (\%) & All areas (\%) \\
\hline Consumed as edible oil & 64 & 100 & 82 \\
Can be eaten as dish of boiled sunflower & 8 & - & 4 \\
Can be eaten as fry like groundnut & 8 & 4 & 6 \\
By-product use as fuel & 40 & 50 & 45 \\
\hline
\end{tabular}

Utilization of sunflower at traders' level: The use of sunflower is limited in Bangladesh. Majority of the farmers (79\%) mentioned that traders used sunflower to extract edible oil and rest of them (21\%) mentioned that they don't know about the use of sunflower at traders' level (Table 26).

Table 26. Farmers' perception about utilization of sunflower at traders' level

\begin{tabular}{l|c|c|c}
\hline Utilizations & Bogra (\%) & Satkhira (\%) & All areas (\%) \\
\hline To produce edible oil & 66 & 92 & 79 \\
Don't know & 34 & 8 & 21 \\
Total & 100 & 100 & 100 \\
\hline
\end{tabular}




\subsection{Technical Efficiency of Sunflower Growers}

Technical efficiency and associated inefficiency factors: The results of the estimated parameters of the stochastic frontier and the inefficiency model are presented in Table 27. The variance parameters for $\delta^{2}$ and $\gamma$ are 0.299 and 0.284. They are significant at 5\% and $1 \%$ level respectively. The sigma squared $\delta^{2}$ indicates the goodness of fit and correctness of the distributional form assumed for the composite error term while the gamma $\gamma$ indicates that the systematic influences are un-explained by the production. Function and the dominant sources of random errors show that the inefficiency effects make significant contribution to the technical inefficiencies of farmers.

The coefficient of human labour (0.309) is found positive and significant at 5\% level. It indicates that if the number of labour is increased by $1 \%$ then the yield of sunflower will be increased by $0.31 \%$. This shows the importance of labour in sunflower farming in the study area. Some studies (Rahman, 2000; Baksh, 2008) have shown the importance of labour in farming, particularly in developing countries where mechanization is only common in big commercial farms. In the study area, farming is still at the subsistence level generally. Human labour plays crucial role in virtually all farming activities.

The coefficient of seed $(-0.177)$ is negatively significant implying that if the farmers increase the use of seed by $1 \%$ then their yield of sunflower will be decreased by $0.18 \%$. Since farmers sow sunflower seed in line less seed is required.

The coefficients of irrigation cost (0.519), organic fertilizer (0.331) and land type dummy $(0.250)$ are positively significant which indicates that, if the use of irrigation and organic fertilizer is increased then the yield will be increased. Land type dummy indicates if the farmers cultivate sunflower in the medium high land they will get more yield than other farmers who cultivate it on other types of land.

Inefficiency effects: The estimated co-efficients of technical inefficiency model showed that educational level and family size had significantly positive effect on the efficiency of sunflower production. It means that technical inefficiency in sunflower production decreases with the increase in farmers' educational level and family size (Table 27). This is because educated farmers used all inputs relatively optimum level and the farmers having more family members can take care efficiently to their farm. Coelli and Battese (1996), Sharif and Dhar (1996), Seyoum et al. (1998) observed significant positive correlation with education and efficiency. 
Table 27. Maximum likelihood estimates of the stochastic frontier function and technical inefficiency

\begin{tabular}{|c|c|c|c|c|}
\hline Variables & Parameters & Coefficients & Standard error & t-ratio \\
\hline \multicolumn{5}{|l|}{ Production frontier } \\
\hline Constant & $\beta_{0}$ & $6.304 * * *$ & 1.540 & 4.091 \\
\hline Human labour $\left(\mathrm{x}_{1}\right)$ & $\beta_{1}$ & $0.309 * *$ & 0.154 & 2.001 \\
\hline seed $\left(x_{2}\right)$ & $\beta_{2}$ & $-0.177 *$ & 0.103 & -1.721 \\
\hline Land preparation cost $\left(\mathrm{x}_{3}\right)$ & $\beta_{3}$ & 0.147 & 0.212 & 0.695 \\
\hline Irrigation cost $\left(\mathrm{x}_{4)}\right.$ & $\beta_{4}$ & $0.519 * *$ & 0.261 & 1.986 \\
\hline Organic fertilizer $\left(\mathrm{x}_{5}\right)$ & $\beta_{5}$ & $0.331 * *$ & 0.156 & 2.125 \\
\hline Chemical fertilizer $\left(\mathrm{x}_{6}\right)$ & $\beta_{6}$ & 0.093 & 0.094 & 0.987 \\
\hline Land type dummy $\left(\mathrm{D}_{1}\right)$ & $\eta_{1}$ & $0.250 * * *$ & 0.083 & 3.001 \\
\hline \multicolumn{5}{|l|}{ Inefficiency function } \\
\hline Constant & $\delta_{0}$ & $-0.1324 * * *$ & 0.046 & -2.869 \\
\hline Age $\left(z_{1}\right)$ & $\delta_{1}$ & 0.257 & 0.564 & 0.456 \\
\hline Education $\left(\mathrm{z}_{2}\right)$ & $\delta_{2}$ & $-0.104 * * *$ & 0.039 & -2.639 \\
\hline Household size $\left(\mathrm{z}_{3}\right)$ & $\delta_{3}$ & $-0.102 * *$ & 0.051 & -1.986 \\
\hline Farm size $\left(\mathrm{z}_{4}\right)$ & $\delta_{4}$ & -0.201 & 0.213 & -0.943 \\
\hline \multicolumn{5}{|l|}{ Variance parameters } \\
\hline Sigma-squared & $\sigma^{2}$ & $0.299 * *$ & 0.143 & 2.088 \\
\hline Gamma & $\gamma$ & $0.284 * * *$ & 0.062 & 4.588 \\
\hline Log likelihood function & & 0.352 & & \\
\hline
\end{tabular}

Individual farm technical efficiency scores: The technical efficiency scores of each respondent were estimated and have been presented in Table 28. All the respondents were found to be more than $70 \%$ technically efficient. Average technical efficiency of the farmers was $86 \%$ which implies that there is a scope of increasing productivity (14\%) by increasing efficiency of the farmers. The most efficient farmer operated at $97 \%$ efficiency, while the least efficient farmers were found to operate at $72 \%$ efficiency level. The result indicates that if the farmers having average efficiency could achieve the TE level of their most efficient counterpart, then they could increase their productivity by $11 \%$ [1-(86/97)]. Similarly, the most technically inefficient farmers could increase the productivity by $26 \%$ [1-(72/97)], if they could increase the level of TE to their most efficient counterpart. This increased productivity will contribute to increase production of sunflower which will have positive effects on cutting of import dependency. 
From the results obtained, although farmers were generally relatively efficient, they still have room to increase the efficiency in their farming activities to attain optimum (100\%) efficiency level.

Table 28. Distribution of technical efficiency scores

\begin{tabular}{lccc}
\hline Efficiency levels & No. of farmers & \% of total farmers \\
\hline $0.70-0.79$ & 46 & 46 \\
$0.80-0.89$ & 37 & & 37 \\
$0.90-1.00$ & 17 & & 17 \\
Mean efficiency level & & 0.86 & \\
Minimum & & 0.72 \\
Maximum & 0.97 \\
Number of observations & & 100 \\
\hline
\end{tabular}

\subsection{Potentialities of Sunflower Cultivation}

Effects of sunflower cultivation: Sunflower cultivation is easy and its production cost is low. Owing to its lower production cost and higher return, farmers in the study areas (45\%) mentioned that, they are becoming solvent. Due to cultivating sunflower $46 \%$ farmers of Satkhira district mentioned that, their demand for edible oil and nutrition has been fulfilled to some extent. A good number of female farmers (18\%) were also found to be interested to cultivate sunflower due to its beauty and easy cultivation method.But in Bogra district, $26 \%$ farmers pointed out that, the impact of sunflower cultivation on household was not prominent (Table 29).

Table 29. Effects of sunflower cultivation on the farm household

\begin{tabular}{l|c|c|c}
\hline Particular & Bogra (\%) & Satkhira (\%) & All areas (\%) \\
\hline Increase in financial solvency & 40 & 50 & 45 \\
Meet up household demand for edible oil & - & 46 & 23 \\
Female farmers are becoming interested to cultivate & 26 & 10 & 18 \\
Change is not prominent & 26 & - & 13 \\
\hline
\end{tabular}

\subsection{Problems of Production and Marketing of Sunflower}

Lack of irrigation facility was acute problem of producing sunflower in Satkhira district. They also mentioned that scarcity of seed on time (24\%), insect infestation (20\%) and disturbance of birds (14\%) were severe problems. But the farmers of Bogra district were more commercial as they mentioned more of marketing problems. They mentioned that there was no sunflower oil crushing mill $(30 \%)$ and market for sell $(44 \%)$, scarcity of seed $(46 \%)$, low demand $(30 \%)$, high seed cost $(26 \%)$ etc. as major problems of sunflower production and marketing (Table 30). 
Table 30. Problems of sunflower production and marketing in the study areas

\begin{tabular}{l|c|c|c}
\hline \multicolumn{1}{c}{ Type of Problems } & Bogra (\%) & Satkhira (\%) & All areas (\%) \\
\hline Lack of irrigation & - & 52 & 26 \\
Have no market for sell & 44 & - & 22 \\
Scarcity of seed & 46 & 24 & 20 \\
No oil crushing mill & 30 & - & 15 \\
Low demand & 30 & - & 15 \\
Cost of seed is high & 26 & 2 & 14 \\
Insects infestation & - & 20 & 10 \\
Birds cause disturbance & 6 & 14 & 10 \\
Problem of stolen & 10 & 2 & 6 \\
Low price & 8 & 4 & 6 \\
Leaf drying disease & 2 & 2 & 2 \\
Root rotten disease & 4 & - & 2 \\
Smut of corn & 2 & - & 1 \\
Higher cost of production & 2 & - & 1 \\
Plant falls on ground owing to rain & 2 & - & 1 \\
\hline
\end{tabular}

\subsection{Actions Needed for Sustaining Sunflower Cultivation}

Respondent farmers suggested some actions that are needed for sustaining sunflower cultivation in the study areas. They mentioned that sunflower oil mills and sunflower markets should be established. They also mentioned that seed should be available in time and cost of seed should be decreased. Irrigation facility should be made available for farmers especially in Satkhira district. Farmers of Bogra district emphasized on selling certainty (58\%), establishment of oil crushing mill (76\%) and reducing seed cost (20\%) to sustain sunflower cultivation (Table 31).

Table 31. Actions needed for sustaining sunflower cultivation in the study areas

\begin{tabular}{|c|c|c|c|}
\hline Suggestions & Bogra $(\%)$ & Satkhira $(\%)$ & All areas $(\%)$ \\
\hline Will have certainty of selling & 58 & - & 29 \\
\hline Irrigation system should be developed & - & 54 & 27 \\
\hline Establishment of oil crushing mill & 76 & - & 38 \\
\hline Availability of seed in time & 10 & 26 & 18 \\
\hline Price of seed should be decreased & 20 & - & 10 \\
\hline Insect attack should be controlled & - & 12 & 6 \\
\hline Arrangement of training & - & 10 & 5 \\
\hline Demand should be increased & 10 & - & 5 \\
\hline Marketing system of sunflower should be developed & 8 & - & 4 \\
\hline Price should be increased & 4 & 4 & 4 \\
\hline
\end{tabular}




\section{Conclusion and Recommendations}

\subsection{Conclusion}

The present study has been conducted to assess the current socioeconomic status of sunflower cultivation in Bangladesh. Respondent farmers are very much enthusiastic towards sunflower cultivation. Most of the farmers were 35 to 49 years old. A good number of female farmers were also found to cultivate sunflower due to its beauty and easy cultivation method. Most of the farmers had primary level of education. Nearly every one of the farmers had agriculture as main occupation and most of them were small farmer. Annual income of the selected farmers was Tk. 25000 to 100000 . Majority of the farmers had only one year experience of sunflower cultivation. Largest part of the farmers cultivated sunflower with the help of non-government organization (BRAC). Majority of the farmers cultivated high sun-33 variety of sunflower. In the study areas, farmers cultivated sunflower during rabi season (mid-November to midDecember). Most of the farmers sowed seed in line and only $6 \%$ farmers of Satkhira district followed broadcasting method of sowing. They performed some intercultural operations like weeding, spraying, and irrigating the crop. The average number of weeding, irrigation, and insecticide spraying per farm were 3 , 2 , and 1.5 respectively. The harvesting time of sunflower started in the month of March and continued up to the month of April. Sunflower cultivation at farm level is reported to be profitable since per hectare yield and gross return of sunflower are 2.09 ton and Tk. 73,163 respectively. Again, the per hectare net return and BCR from sunflower cultivation are found Tk. 10,863 and 1.18 respectively which further indicate that sunflower cultivation is profitable. Functional analysis reveals that the use of labour, seed, organic fertilizers, cost of irrigation, and land type have positive and significant effect on the productivity of sunflower. Average technical efficiency of the farmers is $86 \%$ which implies that there is a scope of increasing the productivity of sunflower (14\%) using current level of inputs by increasing the efficiency of farmers. Although sunflower is a profitable crop, respondent farmers face various socioeconomic problems during its cultivation and marketing. The major problems are lack of irrigation facility, scarcity of seed on time, absence of sunflower oil mill and sunflower market, low demand for sunflower, and high cost of seed. In spite of having some problems a good number of female farmers are being involved in sunflower cultivation and $46 \%$ farmers of Satkhira district mentioned that their demand for edible oil is becoming fulfil. So there is great potentiality of sunflower cultivation in Bangladesh. The availability of improved seed with low cost and establishment of sunflower oil crushing mill is needed to sustain sunflower cultivation in Bangladesh. 


\subsection{Recommendations}

From the study it should be recommend that seed of sunflower should be made locally available to the farmers. So, Government should encourage BADC and private seed companies to produce sunflower seed and supply those seeds to the farmers at reasonable price. Government may also encourage farmers to store seeds by imparting training on seed storage technique and disseminate those to the other enthusiastic farmers. Marketing system of sunflower should be developed by creating local assemble market in the sunflower growing areas. For this awareness should be made among the farmers about its use and importance. Government and private enterprises should work together to develop agribusiness of sunflower. To expand market opportunities for farmers and reduce import dependency, sunflower oil crushing mill should be established in the growing areas. Though BRAC has taken initiatives to set up an oil crushing mill in Khulna and Barisal region, government and other private organization should take initiative to establish sunflower oil crushing mill in the local areas. To reduce irrigation problem and increase sunflower production in southern part of Bangladesh saline tolerant short duration sunflower variety will be developed. Finally, increased production and marketing of sunflower seed will help us cut our import dependence on soybean oil. Therefore, more intensive research should be undertaken to develop short duration sunflower varieties in the near future.

\section{References}

Anonymous. 2014. Krishi Projukti Hathboy (Handbook on Agri-technology), sixth Edition, Vol. 1, BARI, Joydebpur, Gazipur.

Anonymous. 2015. Sunflower farming gains popularity in Barisal. In "The Daily Star", 22 May 2015, Dhaka. P. 7.

Baksh, M., M. Kabir, M. S. Mandal. 2008. Socio-economic study on sustainability of wheat production in northern region of Bangladesh. Annual Report (2007-08), BARI, Nashipur, Dinajpur-5200, Bangladesh. Pp. 129-134.

BB. 2014. Annual Import Payments 2013-2014, Bangladesh Bank, Bangladesh. P. Lxiii.

BBS. 2012. Yearbook of Agricultural Statistics. Bangladesh Bureau of Statistics. The Government of Peoples Republic of Bangladesh.

Coelli, T. J. and G. E. Battese. 1996. Identification of factors which influence the technical inefficiency of Indian farmers. Australian J. Agril. Economics. 40(2): 103128.

Freund, J. E. and F. J. Williams. 1983. Modern Business Statistics, London: Pitman.

Gabagambi, D. M. and V. George. 2010. Sunflower production situation in the central corridor of Tanzania. Final Report, Rural Livelihood Development Company, Tanzania. 
Miah, M. A. M., M. A. Rashid and S. M. A. Shiblee. 2014. Assessment of Socioeconomic Impacts of Oilseed Research and Development in Bangladesh. Final report submitted to PIU-BARC, NATP: Phase-1, BRAC complex, Farmgate, Dhaka1215.

Miah, M. A. M., M. A.Rashid, S. M. A. Shiblee and S. Afroz. 2013. Adoption and profitability of oilseed cultivation in Bangladesh. Annual Research report (2013-14), Agricultural Economics Division, BARI, Gazipur, Bangladesh. Pp. 33-67 .

Rahman K. M. M., P. M. Schmitz and T. C. Wronka. 2000. A translog stochastic production frontier analysis on the estimation of technical efficiency of rice production in Bangladesh. J. Bus. Adm. 26 (2\&3): 15-46.

Rahman M. M. 2012. Enhancement of resilience of coastal community in Bangladesh through crop diversification in adaptation to climate change impacts. A Dissertation for the Degree of Masters in Disaster Management, BRAC University, Dhaka, Bangladesh.

Rashid , M.H., S. Nasrin and D.Mahalder. 2014. "Zero Tilled Dibbled Sunflowers Enables Planting Earlier and Harvests More in the Coastal Saline Area of Bangladesh.” International Journal of Environmental Science and Development, Vol. 5, No. 3 .

Sales, A. 2011. Production of biodiesel from sunflower oil and ethanol by base catalyzed transesterification. MS Thesis, Department of Chemical Engineering, Royal Institute of Technology (KTH), Stockholm, Sweden.

Sharif, N. R. and A. A. Dar. 1996. Stochastic frontiers and technical efficiency distributions: An analysis based on rice farming data for Bangladesh. Canadian Journal of Economics. 29 (Special Issue). Pp. 582-586.

Sencar, O., S. Gokmen, A. Yildirim and N. Kandemir. 1991. Field crops production. Cumhuriyet University, Agriculture Faculty Publications, Tokat. Publication No.11, P. 150

Seyoum, E. T., G. E. Battese, and E. M. Fleming. 1998. Technical efficiency and productivity of maize producers in Eastern Ethiopia: A study of farmers within and outside the Sasakawa-Global 2000 project, Agricultural Economics. 19(3): 341-348.

Hossain, S. 2014. Sunflower farming trebles in Patuakhali. In "The Daily Star", 10 April 2014, Dhaka. P.7. 